\title{
Pollution minimizing at traditional craft village by micro-credit program - case study from Tan Phu Dong rice flour production village
}

\author{
Giảm thiểu ô nhiếm bằng nguồn quỹ tín dụng nhỏ - Truờng hợp cu thể ở làng \\ nghề làm bột truyền thống Tân Phú Đông
}

Event report

Nguyen, Vo Chau Ngan ${ }^{1}$; Huynh, Thi Ngoc Luu ${ }^{1}$; Le, Hoang Viet ${ }^{1}$; Do, Ngoc Quynh ${ }^{2}$; Nguyen, $\mathrm{Ngoc} \mathrm{Em}^{3}$

${ }^{I}$ College of Environment \& Natural Resources; ${ }^{2}$ Office of International Relationship; ${ }^{3}$ College of Technology, Cantho University, Vietnam

\begin{abstract}
This paper introduces the results of a project initiated by Cantho University (CTU) on the introduction of micro-credits for addressing the environmental pollution in Vietnam's craft villages. At Tan Phu Dong, a traditional rice flour production village in Sa Dec, Dong Thap, all wastes from domestic and production activities and animal husbandry were freely disposed into open water sources. This practice led to a negative impact on the local environment. With the financial support provided by the Bread for the World (BfdW), a micro-credit program was initiated in which farmers could borrow money to construct a biogas plant to treat animal husbandry and domestic wastes. In addition, the staff transferred biogas plant construction technology to the local masons and organized training courses on biogas plant operation and maintenance and biogas usage for the farmers and the local officials. 61 farmers borrowed money from the program to construct their biogas plants, followed by more than 250 farmers that constructed their biogas plants by their own finance after realizing the positive benefits of biogas plants. As result, the environmental pollution issue was solved step-by-step, thereby helping enhance the living conditions of the local community.

Bài báo này trình bày biện pháp sủ dụng nguồn quỹ tín dụng nhỏ để các hộ dân cải thiện tình trạng ô nhiếm môi truòng ở các làng nghề Việt Nam. Tại làng nghề làm bột Tân Phú Đông - Sa Đéc - Đồng Tháp, các loại chất thải sinh hoạt, chất thải sản xuất và chăn nuôi xả thải bùa bãi đã gây ô nhiễm môi trường nghiêm trọng. Với kinh phí tài trọ tù tổ chức Bánh mỳ cho thế giới (BfdW), các cán bộ truờng Đại học Cần Tho đã tổ chưc cho nguời dân luân phiên vay vốn để xây dụng hầm ủ khí sinh học xủ lý chất thải chăn nuôi và chất thải sinh hoạt. Bên cạnh đó còn tổ chức các lớp tập huấn chuyển giao công nghệ xây hầm ủ khí sinh học cho thợ xây địa phuơng, huớng dẫn vận hành và bảo duỡng hầm ủ cho người dân và cán bộ địa phuơng. Thông qua nguồn vốn vay của dụ án, có 61 hộ dân đã xây dưng hầm ủ khí sinh học và trên 250 hộ dân khác đã tụ đầu tu xây dựng khi thấy được lợi ich của hầm ủ. Nhờ đó tình trạng ô nhiếm môi truòng tùng bước được giải quyết góp phần cải thiện điều kiện sống của nguời dân tại địa phuơng.
\end{abstract}

Keywords: micro-credit, rice flour production, TG-BP biogas plant, Tan Phu Dong craft village

\section{Introduction}

Traditional craft villages play an important role in local economic development in Vietnam. It is estimated that there are 1.4 million households in rural Vietnam with 11 million labourers working in 4,600 craft villages throughout the country (EPA, 2009). Particularly in the Mekong Delta (MD) with over 200 craft villages, these small enterprises are drawing the participation of at least $30 \%$ of all households and making at least $50 \%$ of the village's total income (World Bank, 2012). The traditional craft 
villages create new jobs for rural people who do not have farmland, make use of the extra labour of farmers when they are free from their cultivation, and exploit local comparative advantages. By doing so, the traditional craft villages have significant contribution to poverty alleviation and transformation of the economic and labour structure in rural Vietnam in the process of rural industrialization and modernization. However, the production activities of the craft villages have caused some environmental problems which can affect the health of local residents.

Tan Phu Dong is a commune located along Sa Dec River in Sa Dec District of Dong Thap Province (Figure 1). Having specialized in rice flour production roughly for 100 years, Tan Phu Dong is recognized to be a traditional craft village of rice flour processing. More than 3/4 of local households in this village produce rice flour. Every day, each household processes about $100 \div 140 \mathrm{~kg}$ of rice to make $70 \div 100 \mathrm{~kg}$ of rice flour, $30 \div 40 \mathrm{~kg}$ of the lees and $2 \div 3 \mathrm{~m}^{3}$ of wastewater. To salvage the by-product of the rice flour processing, the lees were used as feed for pig breeding (see the flow diagram of rice flour processing in Figure 2). In average, almost every rice flour processing household raises $40 \div 60$ pigs.
However, at Tan Phu Dong the wastewater from the processing as well as from the pigsty is directly disposed into the surrounding canal network without any treatment. In addition, the wastewater of human activities is also freely discharged into the same canal (Figure 3). These practices have been attributed to the pollution of the local water sources. More seriously, the water from the surrounding canal is used as water supply source for the whole domestic and production activities in this village. This raised a big concern on the sanitation and the health of the local community.

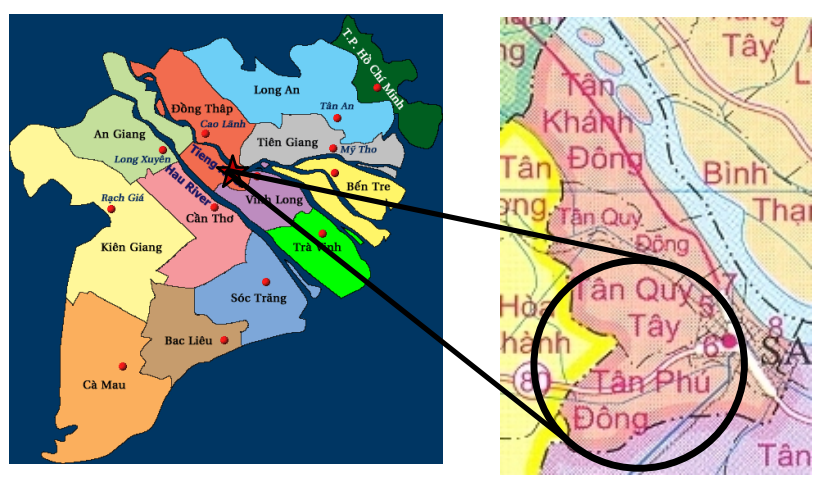

Figure 1. Map of project area

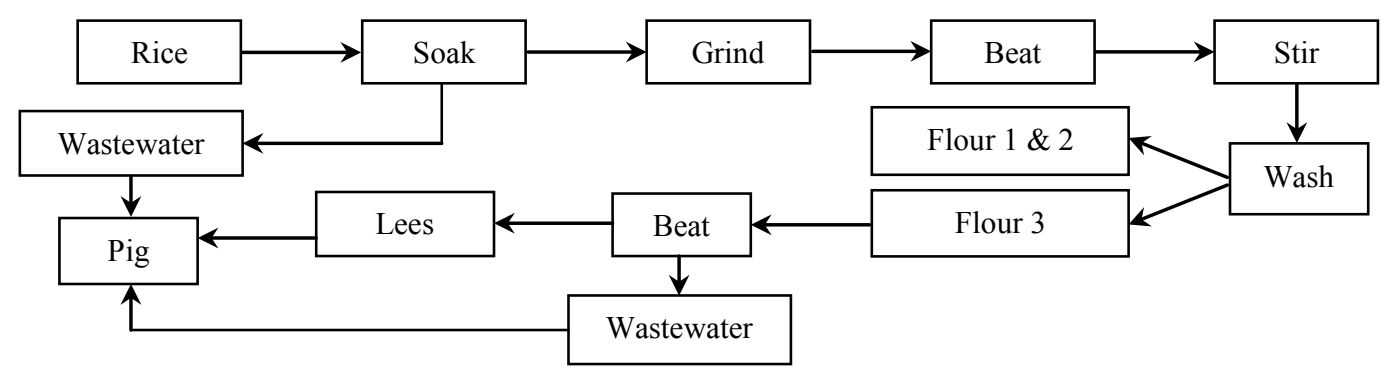

Figure 2. Flow diagram of rice flour processing

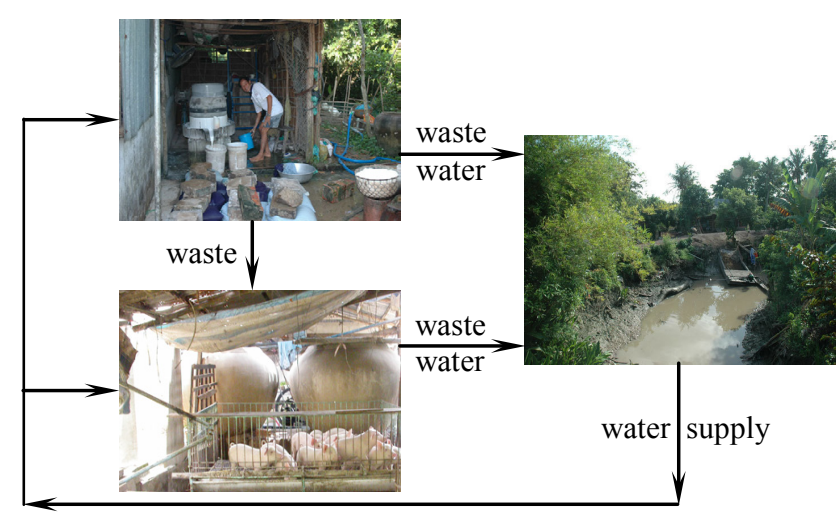

Figure 3. Water-cycle at the Tan Phu Dong village

\section{The approach}

To solve the above mentioned environmental problems, a TG-BP biogas plant model (Nguyen et al., 2012) was introduced to the local community as a treatment system for wastewater from pigpen. Five TG-BP biogas plants were installed at five privately owned enterprises in Tan Phu Dong as the first testing of the wastewater treatment. After the application of the TG-BP biogas plants, the sanitation problems at these pilot households were solved effectively. At these households, there was no bad smell come from the pigpen; the pig dung was treated by the biogas plant, but not discharge into the canal as previous time; the effluent from the biogas plant which disposed into the surrounding canal much better than the un-treated pig dung; and in additional, farmers applied biogas for cooking that saving the money to buy the fire-wood.

Even though the TG-BP biogas plant helped to treat the wastewater, the local farmers could not make use of this technology due to its high investment cost (only few farmers could build a biogas plant without financial help). As such, the environmental problems were still of great concern to the local community at Tan Phu Dong.

Thank to the financial support provided by the Bread for the World (BfdW) program, the project "Promotion of commercialization of biogas plants" has started to install more biogas plants at Tan Phu Dong village. The project objectives are (i) improvement of community's sanitation and rural people's health, (ii) effectively spreading biogas technology and developing a commercial viable biogas sector in the project area, and (iii) contributing to rural development and environmental protection via provision of clean and affordable energy to rural households. 


\section{Framework conditions}

Tan Phu Dong had some outstanding characteristics which facilitated the application of the microcredit program to promote biogas technology development:

\section{$\underline{\text { Economic frameworks }}$}

- Rapid economic growth;

- Changes in the agricultural sector;

- Increased achievement of the benefits from waste reduction and energy cost by using biogas systems.

\section{$\underline{\text { Socio-cultural and socio-economic frameworks }}$}

- Acceptance and acknowledgement of technology due to small scale use of biogas;

- Experts from Cantho University (CTU) play an important role to disseminate the knowledge;

- No technical supporting services at the local area;

- No financial assistance from administrative authorities;

- Good base for community projects.

Legislative, regulatory and policy frameworks

- Several government policies required the application of environment protection technologies;

- Good results from application of biogas system to treat husbandry waste;

- Research and development programs in relation to biogas aspect initiated by CTU.

\section{Project activities}

\subsection{Micro-credits}

The Project provided micro-credits to the local farmers who would like to install biogas plants. This support gave priority to the poor households who were selected based on the evaluation and suggestion made by the local authority. The micro-credits were handed on directly to the selected farmers and the loans had to be repaid after 6 months, and only then the credits were redistributed to other farmers. The money was transferred directly to the household on the name of household's head who was also the owner of the biogas plant.

In Phase 1, there were two types of loans (i) the loan used for construction of biogas plants for very poor farmers, and (ii) the loan for quality control of the biogas plants for the poor farmers.

\subsubsection{Support for the construction of biogas plants}

In Phase 1, the Project provided credits to 21 poor farmers to construct 21 biogas plants with volumes from 4 to 18 $\mathrm{m}^{3}$ (the total volume of the constructed plants was 198 $\mathrm{m}^{3}$ ). This activity was implemented by the following procedure:

- Selection of the beneficiary farmers: the beneficiary farmers must meet the following qualifications:

$\checkmark$ Having the basic conditions for installation of a biogas plant and being willing to invest in a biogas plant, living in a very poor situation and being nominated by the local authority to be eligible to participate to the Project.

Being available to attend the biogas training courses and to assist the technicians during the whole construction process. Committing to continue to follow the technical requirements on biogas plant operation and maintenance works.

- Construction of biogas plants: the Project's technicians were in charge of:

$\checkmark$ Constructing seven demonstration TG-BP biogas plants for the selected households according to the provided design drawing (Figure 4).

$\checkmark \quad$ Providing technical assistance to the farmers during and after the construction.

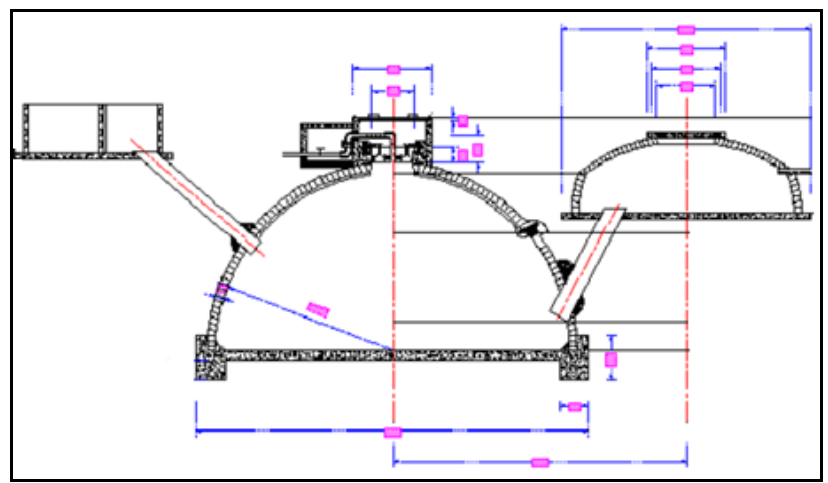

Figure 4. The sketch of constructed TG-BP plant (Source: Cantho University, 2002)

\subsubsection{Support for quality management of the plant}

Construction quality management is one of the key activities of the Project. In this Project, only seven biogas plants were constructed by CTU's technicians. The remaining plants were built by local technicians who had taken training courses on construction of biogas plants. One staff from the local authority had been trained as a supervisor to control the construction of the biogas plants constructed by local technicians. The Project established a comprehensive control procedure to ensure the biogas plant quality. The quality control work was financially supported by the owners of the biogas plants.

In case a farmer could construct a biogas plant by his/her self supported finance, the Project offered him/her the 
credit for the quality management cost only. In Phase 1, the Project supplied loans to 40 households for the biogas plant quality control with total volume of $316 \mathrm{~m}^{3}$.

\subsection{Training and dissemination}

\subsubsection{Training}

Training for the group of local technicians

- Participants: skilled masons who are active, enthusiastic, and highly responsible.

- Content: to provide the basis knowledge on biogas plants, design principles, construction \& operation; quality standard of materials, equipment, accessories; standard of construction \& installation; labor safety, safety requirements to maintenance in particular; instructional manual; merits \& obligations of masons

$\underline{\text { Training for biogas quality control staff }}$

- Participants: staff from the local authority

- Content: to provide the basis knowledge on biogas plant, design principle, construction and operation; quality standard of materials, equipment, accessories; standard of construction and installation; labor safety, safety requirements to maintenance in particular; instructional manual; rights and obligations of masons and other financial procedures.

\section{$\underline{\text { Training for biogas users on post-construction }}$}

- Participants: the members of the households who are biogas plant users, especially who usually operate the plant, are encouraged to take part in the training.

- Content: to instruct the users how to operate, maintain a biogas plant and related equipments and especially, how to use biogas in flood seasons.

\section{Other trainings}

- Participants: the members of the households who are biogas-users, especially who usually operate the plant, are encouraged to take part in the training.

- Content: to instruct the users how to raise pigs and to guide them through biogas usage, slurry application, and compost application.

\subsubsection{Dissemination}

- The training materials: three user manuals were issued

Manual on construction and operation of the TGBP biogas plant

$\checkmark \quad$ Manual on pig breeding

$\checkmark \quad$ Manual on biogas slurry application
- The television program: the Project was financially supported by the Cantho Television Center who developed a television program entitled "An efficient way to treat pig waste by using biogas plants".

\section{Project strengths and weaknesses}

\subsection{Technical perspective}

TG-BP biogas plant model was developed by the scientists from Germany, Thailand and China within a GTZ's project. Although installed underground, this plant model can adapt to the high groundwater table in the MD. As a fixed-dome plant, this model stores the produced biogas inside the digester, thereby limiting any risks that may happen to the outside gas storage. Additionally, the gas pressure of the TG-BP biogas plant is sufficiently strong to allow the use of the produced biogas for lighting purpose. Moreover, the effluent of the biogas plants can be used as organic fertilizer for fruit trees.

Nevertheless, it is worth noting that since the construction technique of the TG-BP model is complicated and professionally designed, it is required to have well-trained masons building the plant. The local masons, however, had limited knowledge on the design of the plant. Therefore, this was a challenge to the Project.

\subsection{Social perspective}

In Phase 1 of the Project, the CTU's staff played the role of project manager, rising high confidence from the farmers on the Project. Moreover, the fact that the CTU's staff held training courses on biogas plant construction, operation and maintenance, guideline for pig breeding, etc. gave the farmers higher trust in the Project.

Due to the help of the local social organizations such as Women's Union, Farmers' Association, and the like, the Project's staff broadly introduced biogas plants and their benefits to the farmers. This is an important step to bring the biogas plant technology into the community's understanding.

A strong point of biogas plants is not only to treat animal waste but also domestic waste. On construction of a biogas plant, the farmers were asked to connect their toilet pipe into the biogas plants. By this way, the farmers could save money on building a septic tank later. Yet it was acknowledged that a few farmers refused this connection. They accepted to use the output from the biogas plants with pig manure feeding but not the output from the biogas plants with human waste feeding. As such, it is necessary to launch some propaganda programs to change farmers' attitudes towards this mistaken understanding.

\subsection{Economic and financial perspective}

The application of biogas plants to treat the waste from a traditional craft village is an innovative activity in the Mekong Delta. In the past, biogas plants were mostly applied to the VACB (V - garden, A - fishpond, C - pigpen, and B - biogas plant) farming system. In a craft vil- 
lage, farmers have changed their cultivation activities and the economic growth at different level. It is to be expected that farmers in a craft village can get more income compared to the farmers in a sole agricultural cultivationbased place. As such, it seems easier for the farmers in a craft village to accept to construct a biogas plant.

Obviously, the biogas plants bring out many benefits to the owner such as supplying gas for cooking and lighting, saving time on wood-fuel preparation and cooking, providing better sanitary conditions, organic fertilizer source, etc. In fact, the farmers at Tan Phu Dong could refund their investment cost for the construction of the biogas plants after two to three years of the biogas plant operation.

High investment cost is one key barrier to promote the biogas construction at Tan Phu Dong. Even the local farmers acknowledged the benefits of biogas plants, they could seldom afford the installation of a biogas plant by their own expense (especially the poor farmers). Therefore, they need an initial financial support to construct the biogas plant, support which cannot be provided by the local government due to the lack of appropriate budget. However, due to the Project, the farmers could borrow money to invest in a biogas plant and almost all the borrowers could pay back the loans within six months, and the repaid money was available to be lent to other farmers for the next round.

\subsection{Institutional and policy perspective}

The Project brought a positive influence on the local institutions and policy concerning the application of biogas technology and the environment protection. Even though the local farmers were aware of biogas technology, many of them did not want to invest in construction of a biogas plant to treat the waste of their pigsties. In addition, there were no any national regulations or local regulations on husbandry wastewater discharge available to control the disposal of wastewater into open water sources before the Project. After having acknowledged the benefits of biogas technology in waste treatment and in an attempt to address the increasing serious problems concerning the environmental pollution in the area, the local authority stipulated that any household which had no biogas plant would not be allowed to do pig husbandry. More importantly, the local authority managed to frequently check the observation of the regulations by the households. After the issuance of the regulations, more farmers committed to construct biogas plants to treat the waste discharged by their animal husbandry.

\section{Concluding remarks}

A microcredit program to promote biogas technology application has been initiated in Tan Phu Dong rice flour processing village, a traditional craft village in Dong Thap province. In the first phase of this Project, 61 biogas plants were built by the financial support from the microcredit program. After having recognized the benefits of biogas tanks, over 250 other households constructed TGBP biogas plants by their own expense. After realizing the great benefits of biogas plants brought to the project area, the Australian Government funded 200 million Vietnamese dong for Tan Phu Dong to help keep installing the TG-BP biogas plants in this area (Cantho University, 2003). As such, due to the Project on the microcredit provision, the number of the biogas plants constructed in Tan Phu Dong's craft village has increased significantly. These constructed biogas plants help not only address the environmental problems in Tan Phu Dong but also improve the local people's life. The biogas technology application has in fact increased the economic value of the rice flour - a traditional local product - in this area when it helps turn the waste of the rice flour production and husbandry into useful biogas applicable for domestic energy need and organic fertilizers for agriculture.

The dissemination of biogas technology knowledge is another outstanding achievement. The Project has published three guiding leaflets on biogas plants and made one related television program. Therefore, the local farmers who raise pigs or produce rice flour can access these sources and get useful information on biogas plants. The Project helped to raise the community awareness (and even the surrounding communities) on the benefits of biogas plants and promoted the development of biogas application for minimizing the environmental problem in Tan Phu Dong and the surroundings. Thus, the project results can be applied not only in the project area but also to other traditional craft villages. The Project also helps to improve the understanding of the local authority about biogas technology, thereby influencing the institutional arrangement regulating the waste disposal in the area. Moreover, the Project's training courses initially established a well-trained group of biogas construction masons who can continue to contribute their professional skills and knowledge to benefit their local community after the completion of the Project such as building new biogas plants and providing maintenance service to the existing plants. This also helps create new jobs for local people, thereby improving their income.

However, in order to improve the efficiency of the project management, it is recommended that in the next phase, the project coordinators should be the local authority staff who has a close connection to the local community so that they can control the repayment of loans more effectively.

In short, the microcredit program undertaken in Tan Phu Dong represents a best practice example to demonstrate the efficiency of the application of microcredit to introduce biogas technology to a traditional craft village, particularly where there is a lack of self-financial support by local people but with big concern on environmental pollution caused by animal waste from husbandry. Such microcredit programs can be used effectively to initially bring in the knowledge on biogas plant technology and its benefits to protect the environment and improve rural households' income into local community in traditional craft villages.

\section{References}

[1] Cantho University, 2002. Manual on Construction and Operation of the TG-BP biogas plant (in Viet- 
namese)

[2] Cantho University, 2003. Promotion of commercialization of biogas plant in Tan Phu Dong ward, Sa Dec district, Dong Thap province, Viet Nam - Report of phase 1 (in Vietnamese)

[3] EPA, 2009. Craft villages: the prevention and combating violations of environmental laws. Hanoi, 2009 (Vietnam's Environmental Police Agency)

[4] Nguyen, V.C.N., Phan, T.H., Vo, H.N. 2012. Review on the most popular anaerobic digester models in the Mekong Delta. J. Viet. Env. 2(1):8-19

[5] Vietnam's Environmental Police Agency - EPA. 2009. Scientific proceeding: prevention, struggle to minimize the violate on craft village environment. Hanoi: EPA (in Vietnamese)

[6] World Bank, 2012. Environmental Management for Traditional Craft Villages in Vietnam (http: //siteresources.worldbank.org/INTEAPREGTOPEN VIRONMENT/Resources/Envi_Man_Craft_Viet.pdf retrieved on 2012-06-18) 